\title{
Preferences of phytoplankton groups for waters of different trophic status in the northwestern Mediterranean Sea
}

\author{
Mikel Latasa ${ }^{1,4, *}$, Renate Scharek ${ }^{2}$, Montserrat Vidal ${ }^{3}$, Gemma Vila-Reixach ${ }^{3}$, \\ Andrés Gutiérrez-Rodríguez ${ }^{1}$, Mikhail Emelianov ${ }^{1}$, Josep M. Gasol ${ }^{1}$ \\ ${ }^{1}$ Institut de Ciències del Mar (CSIC), Passeig Marítim de la Barceloneta 37-49, 08003 Barcelona, Spain \\ ${ }^{2}$ Centro Oceanográfico de Gijón (IEO), Avda. Príncipe de Asturias 70 bis, 33213 Gijón, Spain \\ ${ }^{3}$ Departament d'Ecologia, University of Barcelona (UB), Diagonal 645, 08028 Barcelona, Spain \\ ${ }^{4}$ Present address: Centro Oceanográfico de Gijón (IEO), Avda. Príncipe de Asturias 70 bis, 33213 Gijón, Spain
}

\begin{abstract}
We examined the preferences of phytoplankton groups for waters of different trophic status by comparing the distribution of 8 main phytoplankton groups during the spring bloom, postbloom, and late stratification periods in the northwestern Mediterranean. Pigment chemotaxonomy (using the CHEMTAX computer program) was applied to estimate the contribution of Prymnesiophyceae, Pelagophyceae, Synechococcus spp., Prochlorococcus spp., Prasinophyceae, Cryptophyceae, Dinophyceae, and Bacillariophyceae to the chlorophyll a (chl a) stock. Particulate organic nitrogen (PON) concentration was used as an indicator of trophic status. PON at the surface was $1.7 \pm$ $1.4,0.57 \pm 0.02$, and $0.37 \pm 0.04 \mu \mathrm{mol} \mathrm{l}^{-1}$ in the bloom, post-bloom, and stratification periods, respectively. During the bloom period, there was a weak stratification and a large chl a biomass. Bacillariophyceae dominated during the bloom period, with a substantial contribution of Prasinophyceae. Prymnesiophyceae and Synechococcus spp. dominated during post-bloom and stratification periods, and Prochlorococcus spp. was a major contributor to biomass in the deep chlorophyll maximum (DCM) during the stratification period. Vertical segregation was also evident for Pelagophyceae, Prymnesiophyceae, and Cryptophyceae, which preferred the DCM to surface layers in non-bloom conditions. The relative distribution of each group combined with PON concentrations in these 3 periods allowed us to calculate a group-specific trophic preference index, which showed its highest values (more eutrophic) for Bacillariophyceae, Prasinophyceae, Cryptophyceae, and Dinophyceae; medium values (mesotrophic) for Prymnesiophyceae, Pelagophyceae, and Synechococcus spp.; and a very low value (oligotrophic) for Prochlorococcus spp. The pigment-group diversity (Shannon index) and evenness were lower during the bloom period.
\end{abstract}

KEY WORDS: Spring bloom - Post-bloom - Stratification - Eutrophic conditions · Oligotrophic conditions

\section{INTRODUCTION}

It has been postulated that marine ecosystem functioning and diversity are very much interdependent (Legendre \& Rassoulzadegan 1996). Recent studies have revealed an unexpectedly high genetic diversity of microorganisms in apparently stable environments (e.g. the deep ocean, Sogin et al. 2006) and significant genetic differences among apparently similar sites separated by only a few miles (Rusch et al. 2007). These findings illustrate the difficulty in unveiling a link between diversity at small scales and ecosystem functioning. It is possible that a large portion of this diversity can be considered redundant in terms of 
function. Thus, some grouping of planktonic organisms becomes a reasonable option when trying to associate diversity and function. There are several ways to classify organisms according to the objective of the study. The size of organisms is a common parameter in studies focused on the metabolic behavior of systems (López-Urrutia et al. 2006); Reynolds et al. (2002) classified freshwater phytoplankton assemblages based on their ecological traits; and Le Quéré et al. (2005) proposed a set of plankton functional groups characterized by their capability to drive major biogeochemical fluxes in oceans.

The taxonomic classification of phytoplankton into 3 large groups such as diatoms, dinoflagellates, and coccolithophores has been related to environmental conditions and marine productivity (Margalef 1978). This link has been demonstrated to apply to the paleoceanographic record (Falkowski \& Oliver 2007). In general, diatoms and red-tide dinoflagellates have been associated with highly productive systems, nonred-tide dinoflagellates with oligotrophic conditions, and coccolithophores in between these 2 extremes. A significant step since Margalef's Mandala (Margalef 1978) has been the inclusion of picoplankton, and especially Synechococcus spp. and Prochlorococcus spp., into the general picture of phytoplankton ecology (Cullen et al. 2002). The widespread use of pigment chemotaxonomy and molecular techniques has shown the importance of other groups in the structure and likely the functioning of phytoplankton populations (Andersen et al. 1996, Not et al. 2005, Liu et al. 2009). However, the association of these other groups with environmental and productivity conditions is still lacking.

Trophic status is a loose and sometimes subjective definition of the condition of an aquatic ecosystem. Eutrophic, mesotrophic, and oligotrophic conditions were initially limnological terms to describe the productivity of lakes (Thienemann 1928, Carlson 1977). Several indices have been proposed to quantitatively describe the trophic condition of water (Vollenweider et al. 1998 and references therein). 'Trophic' derives from the Greek 'trephein', to nourish, and we can argue that it might well reflect just the biomass (Elster 1958) or the potential to form biomass. Here, we have considered the concentration of particulate organic nitrogen (PON) as an indicator of biomass and, therefore, of the trophic status of a system. We have combined the concentration of PON and the distribution of major algal groups to estimate a trophic preference index (TPI) that indicates the relative preference of each phytoplankton group for waters with different trophic status.

We carried out the present study in the northwestern Mediterranean, a temperate area where seasonal and spatial dynamics have been well described (Bosc et al. 2004, D'Ortenzio \& Ribera d'Alcalà 2009). Briefly, surface waters contain moderate levels of chlorophyll a ( $\mathrm{chl} \mathrm{a}$ ) in winter because of intermittent periods of mixing and stratification. This situation lasts until the beginning of March, when the seasonal stratification begins and the spring bloom develops. This bloom becomes weaker as stratification progresses. Stratification is strongest at the end of August and the beginning of September; from then on, decreasing temperatures and stronger winds set up the conditions for increasing mixing and chl a levels at the surface. Our work was performed along a gradient of nutrient concentrations found in the situations of spring bloom, post-bloom, and late summer stratification. The aim of the present study was to examine the preferences of phytoplankton groups for waters of different trophic status by comparing the distribution of 8 main phytoplankton groups during these 3 situations in the northwestern Mediterranean.

\section{MATERIALS AND METHODS}

The study was conducted during 3 contrasting periods in the northwestern Mediterranean. Two oceanographic cruises were carried out on board the RVs 'García del Cid' and 'Cornide de Saavedra', with a total of 3 legs: EF2004, EF2005N, and EF2005S (Fig. 1). The spring bloom situation was studied in March 2005 $\left(\mathrm{EF} 2005 \mathrm{~N} ; 41.45^{\circ} \mathrm{N}, 05.10^{\circ} \mathrm{E}\right)$; a post-bloom situation was found more to the south in April 2005 (EF2005S; $\left.38.20^{\circ} \mathrm{N}, 03.10^{\circ} \mathrm{E}\right)$; a late stratification situation was studied in September 2004 (EF2004) in the same position as the bloom. During the late stratification, 2 stations (Days 5 and 6) were studied east of Menorca $\left(40.00^{\circ} \mathrm{N}, 05.10^{\circ} \mathrm{E}\right)$ because of bad weather in the north. These 3 situations will be referred throughout the text as bloom, post-bloom, and stratification periods, respectively. The system dynamics outlined here have been explained in detail by Bosc et al. (2004) and D'Ortenzio \& Ribera d'Alcalà (2009).

At each station, daily consecutive casts were performed with a 12-bottle Niskin rosette to obtain water from a minimum of 6 depths during a continuous period of $5 \mathrm{~d}$ (bloom), $3 \mathrm{~d}$ (post-bloom), and $6 \mathrm{~d}$ (stratification). Depths were selected from the conductivity, temperature, and depth recorder (CTD) and fluorescence profiles to obtain the most representative chemical and biological sampling profiles. For the September cruise (stratification), a Neil Brown Mark III-CTD (WOCE standard) equipped with a Sea-Tech fluorometer was used. For the March and April legs (bloom and post-bloom), an SBE 911plus CTD equipped with a Sea-Tech fluorometer was used. 


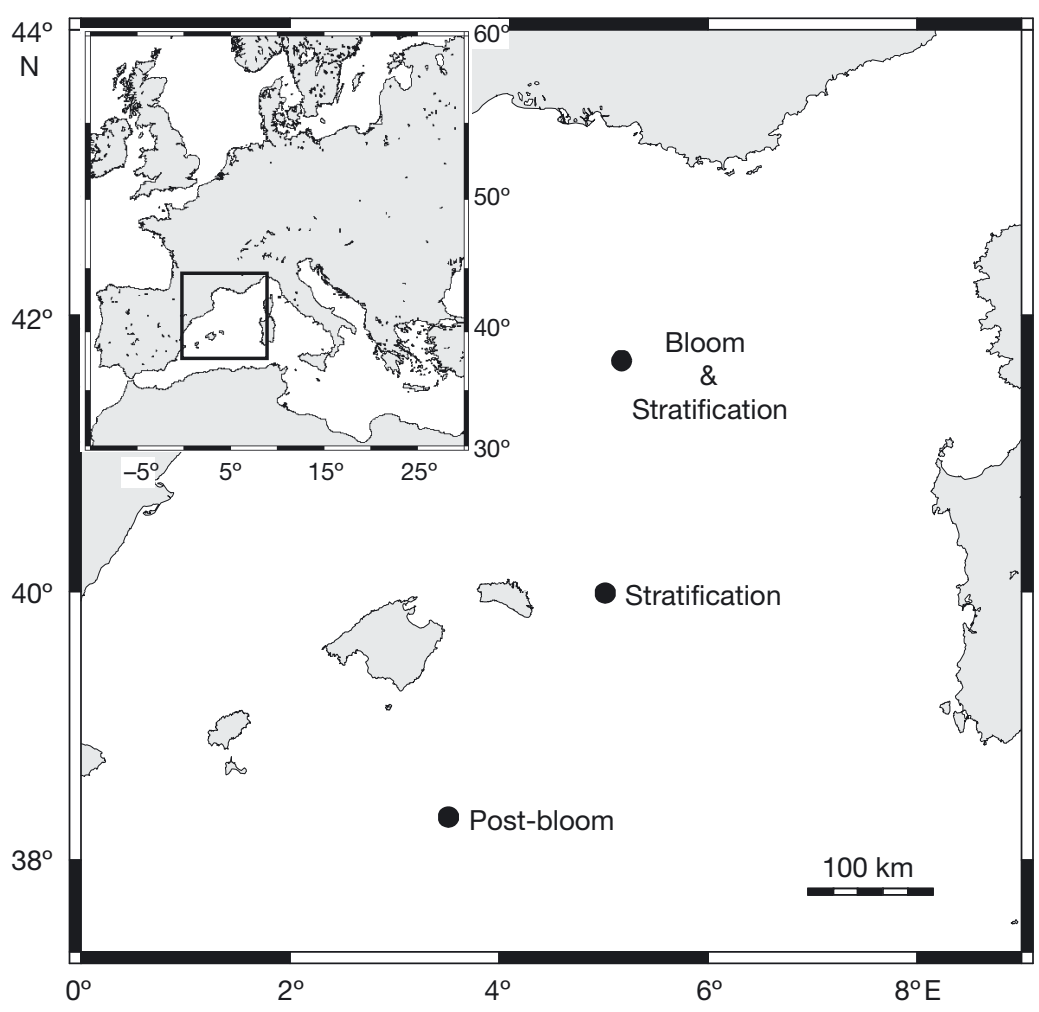

Fig. 1. Map of the sampling sites during the 3 situations studied (bloom, postbloom, and stratification)

Irradiance profiles were obtained with the $2 \pi$ photosynthetically available radiation (PAR; 400 to $700 \mathrm{~nm}$ irradiance) sensor integrated onto a FAST ${ }^{\text {tracka }}$ Fast Repetition Rate fluorometer (Chelsea Instruments). The instrument was deployed daily around noon and directed away from the instrument frame of the ship to avoid shading effects. The measured irradiance values were adjusted using the following exponential equation to estimate the extinction coefficient:

$$
E_{(\mathrm{z})}=E_{0} \times 10^{\left(-K_{\mathrm{PAR}} \times z\right)}
$$

$E_{(\mathrm{z})}$ and $E_{0}$ are the irradiances at depth $z$ and at the surface ( $\mu \mathrm{mol}$ photons $\mathrm{m}^{-2} \mathrm{~s}^{-1}$ ), and $K_{\mathrm{PAR}}$ is the extinction coefficient $\left(\mathrm{m}^{-1}\right)$. The intensity of stratification was estimated by means of the calculation of the BruntVäisälä frequency for each CTD profile.

Water samples for dissolved nutrients were directly filtered from the Niskin bottles through $0.2 \mu \mathrm{m}$ polyethersulfone filters, previously washed in diluted $\mathrm{HCl}$ and rinsed with distilled water. Dissolved nitrate, nitrite, ammonium, phosphate, and silicate concentrations were determined using an Evolution II autoanalyzer (Alliance Instruments), following the methods of Grasshoff et al. (1999). For PON, 41 of water were filtered with positive pressure $(0.3 \mathrm{~atm})$ through precombusted $\left(450^{\circ} \mathrm{C}, 4 \mathrm{~h}\right)$ glass fiber filters (Whatmann $\mathrm{GF} / \mathrm{F})$, which were subsequently placed in plastic vials and frozen in liquid nitrogen. PON concentrations were analyzed in an EA1108 CHNS-O analyzer (Carlo Erba Instruments) after thawing and then drying the filters at $80^{\circ} \mathrm{C}$.

For flow-cytometry quantification of Prochlorococcus spp. and Synechococcus spp., $2 \mathrm{ml}$ of the samples were fixed in the dark for 10 to $30 \mathrm{~min}$ with paraformaldehyde plus glutaraldehyde (1 and $0.05 \%$ final concentrations, respectively; Jacquet et al. 1998), stored in liquid nitrogen during the cruise and transferred to a $-80^{\circ} \mathrm{C}$ freezer after arrival at the laboratory. Less than a month after the cruise, the samples were analyzed with standard protocols (e.g. Olson et al. 1993) on a Becton-Dickinson FACScalibur flow cytometer. Orange and red fluorescence were used to discriminate Prochlorococcus spp. from Synechococcus spp. and picoeukaryotes. Cytometer sample volume was calibrated by weighing the sample tubes before and after measuring runs.

Samples for phytoplankton counts were fixed with formaldehyde buffered with hexamine $(0.6 \%$ final concentration). Cell identification was carried out to the genus and, when possible, to the species level, with an inverted microscope equipped with bright-field and phase-contrast objectives (total magnifications from $100 \times$ to $400 \times$ ) using the Utermöhl method.

For pigment analysis, 21 of seawater was filtered with positive pressure $(0.3 \mathrm{~atm})$ through $25 \mathrm{~mm}$ glass microfiber filters (Whatman GF/F). Filters were folded and blotted dry with laboratory paper and stored in liquid nitrogen. Back in the laboratory, samples were transferred to $\mathrm{a}-80^{\circ} \mathrm{C}$ freezer where they were stored until analysis. Pigments were extracted by placing them in $3 \mathrm{ml}$ of $90 \%$ acetone (with $0.01 \%$ of butylated hydroxytoluene [BHT] to prevent allomerization of chlorophyll) and vortexed vigorously for $45 \mathrm{~s}$. After $24 \mathrm{~h}$ at $-20^{\circ} \mathrm{C}$, samples were sonicated for $1 \mathrm{~min}$ and vortexed again for $45 \mathrm{~s}$. Filter and filter debris were separated from extract by filtration through $0.8 \mu \mathrm{m}$ Poretics polycarbonate filters. The high-performance liquid chromatography (HPLC) system (Thermo) in which samples were analyzed consisted of a P2000 solvent module, an A/S 3000 autosampler, a UV3000 absorbance detector $(\lambda=440 \mathrm{~nm})$, a FL2000 fluorescence detector $\left(\lambda_{\mathrm{ex}}=430 \pm 40 \mathrm{~nm}, \lambda_{\mathrm{em}}=662 \mathrm{~nm}\right)$, and an SN 4000 controller. The column used was a $150 \mathrm{~mm}$ $\times 4.6 \mathrm{~mm}, 3.5 \mu \mathrm{m}$ particle, Waters Symmetry C8 protected with a $3 \mathrm{~mm} \times 4.6 \mathrm{~mm}$ guard column containing 
the same stationary phase. The column was kept at $25^{\circ} \mathrm{C}$ with a recirculating water bath. Batches of ca. 20 samples of $1 \mathrm{ml}$ of extract mixed with $0.2 \mathrm{ml}$ of $\mathrm{H}_{2} \mathrm{O}$ were queued in the autosampler tray at $4^{\circ} \mathrm{C}$ for less than $24 \mathrm{~h}$ to prevent pigment precipitation (Latasa et al. 2001). Samples were run according to a binary gradient based on Zapata et al. (2000) with methanol:acetonitrile:0.25 $\mathrm{M}$ aqueous pyridine solution $(\mathrm{pH}=5)$, 50:25:25 (v:v:v) as mobile phase A, and acetonitrileacetone, 80:20 (v:v) as mobile phase B. The mobile phase gradient was (time, \%A, \%B): $(0,100,0),(10,77$, $23),(23,77,23),(25,65,35),(35,60,40),(38,25,75)$, $(46,15,85),(48,0,100),(57,0,100)$. Flow rate was kept at $1 \mathrm{ml} \mathrm{min} \mathrm{m}^{-1}$. HPLC-grade solvents and analyticalgrade pyridine and acetic acid were from SDS.

With each batch of samples, a chl a standard (Sigma) and a mixture of extracts from known phytoplankton cultures were injected for correcting possible biases in quantification and retention time shifts, respectively. An additional representative sample was run again in the UV3000 detector at fast-scan mode for confirmation of peak identifications by absorbance characteristics. Response factor of detectors against pigment concentration was calibrated with pigment standards (DHI Water \& Environment).

Phytoplankton composition was studied using the chemotaxonomic properties of phytoplankton pigments. Chl $a$, a proxy for total phytoplankton biomass, refers to the sum of monovinyl (MVchl a) and divinyl (DVchl a) chl a throughout the paper. Prochlorococcus spp. contribution to the bulk chl a was estimated directly as DVchl a. All other phytoplankton only contain MVchl a. The contribution of major groups to the bulk MVchl a was quantified using the CHEMTAX program (Mackey et al. 1996). To obtain reliable results, CHEMTAX should be applied to a data set where pigment ratios within the different groups do not change. In order to identify groups of samples with similar pigment ratios, we proceeded the following way: (1) pigment:chl a ratios were calculated; (2) the natural logarithm was applied to standardize the data (before this second step, ratios whose value was zero because pigment concentration was below the detection limit were replaced by 1:3 of the minimum value of that pigment ratio for the whole data set to avoid the irresolution of the logarithm); and (3) cluster analysis was performed with the Statistica software package using the modified pigment:chl a ratios of the following pigments: divinyl chl $c_{3}$, chl $c_{2}$, peridinin, 19'-butanoyloxyfucoxanthin, fucoxanthin, prasinoxanthin, violaxanthin, 19'-hexanoyloxyfucoxanthin, diadinoxanthin, alloxanthin, zeaxanthin, and DVchl a. City-block distances were calculated and samples clustered according to Ward's method. Pigment samples were separated into 2 data sets, one for the stratification period and another one for bloom and post-bloom periods. Cluster analysis was applied to each of the data sets. For the stratification data, the analysis revealed 4 clusters which readily separated samples from the different layers: Cluster 1 comprised samples from 0 to $35 \mathrm{~m}$ depth, Cluster 2 samples from 35 to $50 \mathrm{~m}$ depth, Cluster 3 from the deep chlorophyll maximum (DCM) (68 to $78 \mathrm{~m}$ ), and Cluster 4 samples from 100 to $110 \mathrm{~m}$ depth. For the bloom and post-bloom data set, the analysis discriminated 4 main clusters. An additional distinction between shallow, mid-depth, and deep layers resulted in a total of 7 clusters (some of the original clusters were already restricted to a particular layer). To make this second distinction between shallow, mid-depth, and deep layers, we explored the ratios diadinoxanthin:(19'-hexanoyloxyfucoxanthin + fucoxanthin) and (diadinoxanthin + zeaxanthin):chl a as markers of shifts in pigment ratios due to irradiance and/or nutrients (Latasa 1995). The 2 consecutive analyses applied to the bloom plus post-bloom data set grouped the following samples: Cluster 5: bloom samples from 0 to $15 \mathrm{~m}$ depth; Cluster 6: bloom samples from the DCM (25 to $50 \mathrm{~m}$ ); Cluster 7: bloom samples from below the DCM (100 to $200 \mathrm{~m})$; Cluster 8: post-bloom samples from the very surface ( 0 to $5 \mathrm{~m}$ ); Cluster 9: post-bloom samples from below the DCM (92 to $200 \mathrm{~m}$ ); Cluster 10: post-bloom samples from the middle depth (30 to $50 \mathrm{~m})$; and Cluster 11: post-bloom samples from the $\operatorname{DCM}(52$ to $66 \mathrm{~m})$.

CHEMTAX was applied independently to each of the 11 clusters to obtain the contribution of 7 phytoplankton groups to the MVchl a stock: Prymnesiophyceae, Pelagophyceae, Prasinophyceae, Synechococcus spp., Cryptophyceae, Dinophyceae, and Bacillariophyceae.

Zeaxanthin occurs in Synechococcus spp., green algae, and Prochlorococcus spp. Because Prochlorococcus spp. does not contribute to $\mathrm{MVchl} a$, it is necessary to distinguish between the zeaxanthin contributed by green algae, Synechococcus spp., and Prochlorococcus

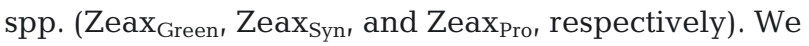
estimated the contribution of $Z_{\text {eax }}$ Green $_{\text {based on viola- }}$ xanthin (common in all green algae) from a regression of zeaxanthin against violaxanthin (ratio $=6.3$, using our unpublished database from the area) when green algae dominate the zeaxanthin-containing phytoplankton. Then we obtained the zeaxanthin from Synechococcus spp. plus Prochlorococcus spp. as

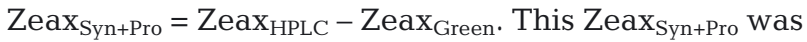
compared to Zeax $\mathrm{FCM}_{\mathrm{F}}=\mathrm{Zeax} \mathrm{Syn}_{\mathrm{cell}}{ }^{-1} \times[\mathrm{Syn}]_{\mathrm{FCM}}+\mathrm{Zeax}$ Pro $_{\text {cell }}{ }^{-1} \times[\text { Pro }]_{F C M}$, where Zeax Syn $_{\text {cell }}{ }^{-1}$ and Zeax Procell $^{-1}$ were the zeaxanthin content per cell (our unknowns) of Synechococcus spp. and Prochlorococcus spp., respectively, and $[\mathrm{Syn}]_{\mathrm{FCM}}$ and $[\mathrm{Pro}]_{\mathrm{FCM}}$ were Synechococcus spp. and Prochlorococcus spp. cell con- 
centrations obtained from flow cytometry for the same sample. Initial values for Zeax $\mathrm{Syn}_{\text {cell }}{ }^{-1}$ and Zeax Pro $_{\text {cell }}{ }^{-1}$ were estimated by minimizing $\Sigma\left(Z_{\text {Zeax }}{ }_{\text {Syn+Pro }}-\right.$ Zeax $\left._{\mathrm{FCM}}\right)^{2}$ using the function Solver in Microsoft Excel in default mode (time $=100 \mathrm{~s}$, Iterations $=100$, Precision $=0.000001$, Tolerance $=5$, Convergence $=0.0001$, Lineal estimation, Progressive derivative, Newton's method). We used a single, common Excel cell for all Zeax $\mathrm{Syn}_{\text {cell }}{ }^{-1}$ with a seed value of $1.8 \mathrm{fg}$ Zeax $\mathrm{Syn}_{\text {cell }}{ }^{-1}$ (Kana \& Glibert 1987). The same procedure was applied for all Zeax Pro $_{\text {cell }}{ }^{-1}$ samples but with a seed value of $1.1 \mathrm{fg} Z$ Zeax Pro cell $^{-1}$ (Cailliau et al. 1996). This procedure provides a single value of Zeax $\operatorname{Syn}_{\text {cell }}{ }^{-1}$ and Zeax $\mathrm{Pro}_{\text {cell }}{ }^{-1}$ for all the samples. A further refinement was to apply Solver a second time allowing the change of all the individual values of Zeax $\operatorname{Syn}_{\text {cell }}{ }^{-1}$ and Zeax Pro cell $^{-1}$.

CHEMTAX was applied following the procedures described in Latasa (2007) using version 1.95 (S. Wright pers. comm.). Random pigment-to-chl a ratios between 0.1 and 1 were used as seed values of 16 input matrices. CHEMTAX was run using the following parameters: ra- tio limits $=500$, initial step size $=10$, step ratio $=1.03$, epsilon limit $=0.000001$, cutoff step $=3000000$, iterations limit $=250$ (only the first run, 120 for the next ones), elements varied $=12$ (number of pigments), subiterations = 1 , Weighting $=$ Bound relative (20). The output of each run was used as input for the following run and this procedure was repeated 3 to 4 times. Another set of 16 random matrices was generated and run as the first set of matrices. This procedure was repeated 2 more times to end with 64 matrices. Because it was difficult to observe a clear convergence of ratio values, the median of each pigment ratio was incorporated to the final pigment ratio matrix. This final matrix was then used to estimate the contribution of the different groups to MVchl a stock. The output values are presented in Table 1. The pigment groups defined here have coherence with taxonomic groups because of their phylogenetic history. However, some species are exceptions to the correspondence shown in Table 1 (Jeffrey \& Wright 2006).

Diversity was estimated using algal groups as the taxonomic unit. The Shannon index $\left(H^{\prime}=-\Sigma p_{i} \ln p_{i}\right.$,

Table 1. Output matrices of pigment to chl a ratios obtained from CHEMTAX for the surface samples of the different periods. Chl $c_{2}$ : chlorophyll $c_{2}$ Per: peridinin; 19'But: 19'-butanoyloxyfucoxanthin; Fuco: fucoxanthin; Pras: prasinoxanthin; 19'Hex: 19'hexanoyloxyfucoxanthin; Allo: alloxanthin; Zea: zeaxanthin; Chl b: chlorophyll b. -: pigment not present in phytoplankton group

\begin{tabular}{|c|c|c|c|c|c|c|c|c|c|}
\hline & $\mathrm{Chl} C_{2}$ & Per & 19'But & Fuco & Pras & $19^{\prime} \mathrm{Hex}$ & Allo & Zea & Chl $b$ \\
\hline \multicolumn{10}{|c|}{ Cryptophyceae } \\
\hline Bloom & 0.36 & - & - & - & - & - & 0.62 & - & - \\
\hline Post-bloom & 0.30 & - & - & - & - & - & 0.67 & - & - \\
\hline Stratification & 0.37 & - & - & - & - & - & 0.74 & - & - \\
\hline \multicolumn{10}{|c|}{ Bacillariophyceae } \\
\hline Bloom & 0.36 & - & - & 0.75 & - & - & - & - & - \\
\hline Post-bloom & 0.12 & - & - & 0.87 & - & - & - & - & - \\
\hline Stratification & 0.22 & - & - & 0.70 & - & - & - & - & - \\
\hline \multicolumn{10}{|l|}{ Dinophyceae } \\
\hline Bloom & 0.38 & 0.65 & - & - & - & - & - & - & - \\
\hline Post-bloom & 0.52 & 0.38 & - & - & - & - & - & - & - \\
\hline Stratification & 0.31 & 0.71 & - & - & - & - & - & - & - \\
\hline \multicolumn{10}{|c|}{ Prymnesiophyceae } \\
\hline Bloom & 0.23 & - & - & 0.17 & - & 0.72 & - & - & - \\
\hline Post-bloom & 0.18 & - & - & 0.28 & - & 0.42 & - & - & - \\
\hline Stratification & 0.22 & - & - & 0.03 & - & 1.01 & - & - & - \\
\hline \multicolumn{10}{|c|}{ Pelagophyceae } \\
\hline Bloom & 0.45 & - & 0.78 & 0.27 & - & - & - & - & - \\
\hline Post-bloom & 0.16 & - & 0.90 & 0.31 & - & - & - & - & - \\
\hline Stratification & 0.27 & - & 0.97 & 0.03 & - & - & - & - & - \\
\hline \multicolumn{10}{|c|}{ Prasinophyceae } \\
\hline Bloom & - & - & - & - & 0.12 & - & - & - & 0.40 \\
\hline Post-bloom & - & - & - & - & 0.09 & - & - & - & 0.58 \\
\hline Stratification & - & - & - & - & a & - & - & - & 0.79 \\
\hline \multicolumn{10}{|c|}{ Synechococcus spp. } \\
\hline Bloom & - & - & - & - & - & - & - & 0.63 & - \\
\hline Post-bloom & - & - & - & - & - & - & - & 0.66 & - \\
\hline Stratification & - & - & - & - & - & - & - & 0.72 & - \\
\hline
\end{tabular}


where $p_{i}$ is the concentration of chl a assigned to a single group by CHEMTAX divided by total chl a) was applied to the phytoplankton communities of surface and DCM layers for each station of the 3 situations.

TPI was calculated by combining the distribution of major algal groups and the concentration of PON as an indicator of the trophic status of the system. The index represents the average of PON weighted by each phytoplankton group for the surface layer at all stations, i.e. for a determined Group A the index would be estimated as $\mathrm{TPI}_{\text {Group A }}=\Sigma\left(\mathrm{PON}_{\mathrm{i}} \times\right.$ Group $\left.\mathrm{A}_{\mathrm{i}}\right) \times$ ( $\Sigma$ Group $\left.\mathrm{A}_{\mathrm{i}}\right)^{-1}$, where PON is PON concentration, Group A is the chl a concentration assigned by CHEMTAX to that phytoplankton group, and $i$ represents each sample. In summary, the group-specific TPI represents the mean PON concentration weighted for the biomass of the group.

\section{RESULTS}

\section{Physical, chemical, and biological characterization of bloom, post-bloom, and stratification}

During the bloom, there was a high degree of physical, chemical, and biological spatial variability. Stratification of the water column was very weak, as revealed by the very small differences in density found occasionally between shallow and deep layers (e.g. $\Delta \mathrm{T}_{5-100 \mathrm{~m}}$ and $\Delta \sigma_{5-100 \mathrm{~m}}$ as low as $0.49^{\circ} \mathrm{C}$ and 0.151 , respectively; the value of 0.125 for $\Delta \sigma$ defines a mixed column, Levitus 1982). Average temperature ranged between $13.6^{\circ} \mathrm{C}$ at the surface and $13.1^{\circ} \mathrm{C}$ at $100 \mathrm{~m}$ depth (Fig. 2). The Brunt-Väisälä frequency was at a maximum between 10 and $40 \mathrm{~m}$ with an average value of 3.2 cycles $\mathrm{h}^{-1}$ and a smooth decrease along the upper $80 \mathrm{~m}$ of the water column. The chl a maximum was distributed between 20 and $40 \mathrm{~m}$ with the occasional presence of secondary maxima at different depths. The high concentrations of phytoplankton quickly absorbed the incident irradiance in the water column; the average attenuation coefficient for PAR $\left(K_{\mathrm{PAR}}\right)$ was $0.147 \mathrm{~m}^{-1}$ and the photic zone ( $1 \%$ irradiance, E) extended to around $35 \mathrm{~m}$ depth. Dissolved inorganic phosphate and silicate followed a depth distribution similar to nitrogen in all situations $\left(r^{2}=0.95\right.$ for phosphate and $\mathrm{r}^{2}=0.96$ for silicate in relation to inorganic nitrogen in the upper $100 \mathrm{~m}$ ). The average concentration of dissolved inorganic nitrogen was $1.9 \mathrm{\mu mol}^{-1}$ at the surface, increasing rapidly up to $8.9 \mu \mathrm{mol} \mathrm{l}^{-1}$ at 40 $\mathrm{m}$ (Fig. 3). PON was $1.7 \pm 1.4$ (SD) $\mu \mathrm{mol}^{-1}$ at surface.

During the post-bloom, there was a weak but defined thermocline at $30 \mathrm{~m}$ depth. Temperature was 14.5 and $13.2^{\circ} \mathrm{C}$ above and below the thermocline, respectively. The Brunt-Väisälä frequency presented a maximum at ca. $30 \mathrm{~m}$ with a value of 8.4 cycles $^{-1}$ coinciding with the thermocline. The DCM was located at 50 to $70 \mathrm{~m}$ depth (Fig. 2). Irradiance (1\% E) penetrated down to $66 \mathrm{~m}\left(K_{\mathrm{PAR}}=0.0658 \mathrm{~m}^{-1}\right)$. Nutrient concentrations were markedly low compared with the bloom period, with minimum values in the first $50 \mathrm{~m}$ (Fig. 3). At the surface, PON was $0.57 \pm 0.02 \mu \mathrm{mol} \mathrm{l}^{-1}$.

In the period of stratification in September, the water column was strongly stratified in the upper $70 \mathrm{~m}$ (Fig. 2). Temperature was $24^{\circ} \mathrm{C}$ in the first $30 \mathrm{~m}$, decreasing to $15^{\circ} \mathrm{C}$ at $60 \mathrm{~m}$ in a steep thermocline. A wide and weak DCM was found at around $73 \mathrm{~m}$, and the $1 \% \mathrm{E}$ was at $71 \mathrm{~m}\left(K_{\mathrm{PAR}}=0.0624 \mathrm{~m}^{-1}\right)$. Nutrient concentrations were low down to $60 \mathrm{~m}$ depth, similar to post-bloom conditions and PON was $0.37 \pm 0.04 \mu \mathrm{mol}$ $\mathrm{l}^{-1}$ at the surface. The Brunt-Väisälä frequency reached maximum values of 18.4 cycles $\mathrm{h}^{-1}$ between 35 and $50 \mathrm{~m}$ depth.

The different stations were characterized according to their pigment markers. Each station was defined according to the depth-distribution of divinyl chl $c_{3}$, chl $C_{2}$, peridinin, 19'-butanoyloxyfucoxanthin, fucoxanthin, prasinoxanthin, violaxanthin, 19'-hexanoyl-
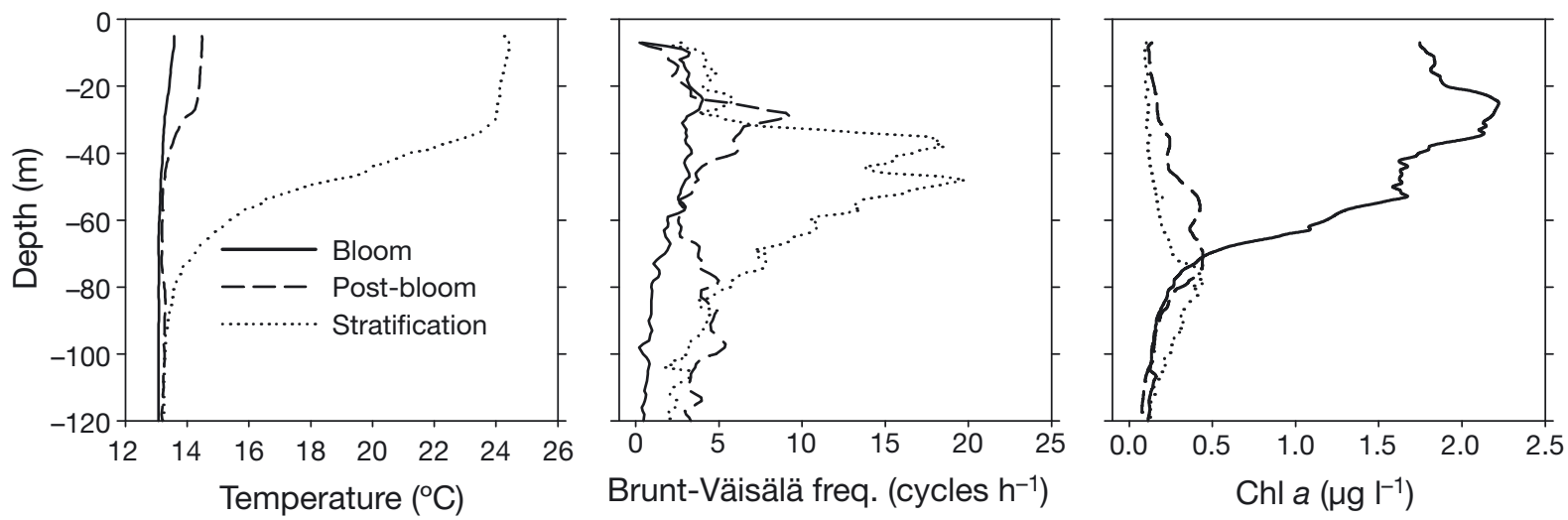

Fig. 2. Vertical profiles of average temperature (left panel), Brunt-Väisälä frequency (middle panel), and chlorophyll (right panel) obtained from CTD casts during bloom, post-bloom, and stratification periods 

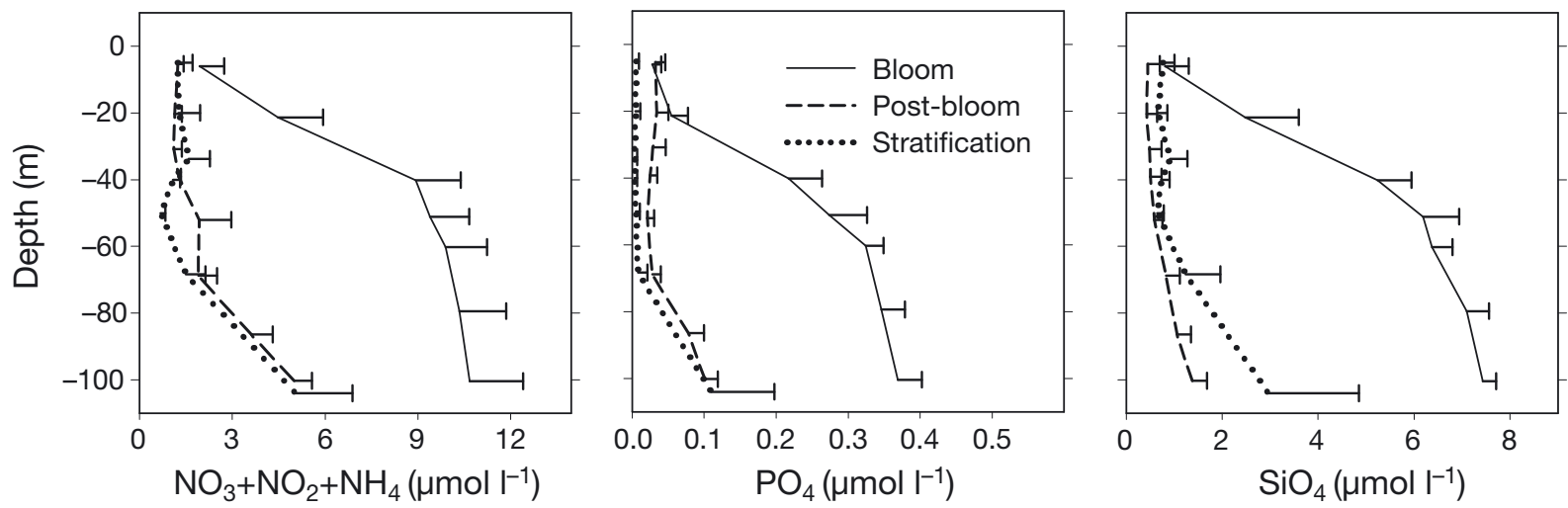

Fig. 3. Profiles of average inorganic nutrient concentrations (left panel: $\mathrm{N}$, middle panel: $\mathrm{P}$, and right panel: Si) during bloom $(n=5)$, post-bloom $(n=3)$, and stratification $(n=6)$ periods. Error bars indicate SD

oxyfucoxanthin, diadinoxanthin, alloxanthin, zeaxanthin, and DVchl a. This means that each station was defined by 12 (pigments) $\times 6$ (depths) = 72 variables. Pigments clearly discriminated the 3 conditions (Fig. 4), with 'bloom' as the most distinct situation. The clustering of all stations during stratification shows that the 2 locations sampled (Days 1 to 4 and Days 5 to 6) were very similar.

\section{Phytoplankton distribution}

In March 2005 (leg EF2005N), we encountered the northwest Mediterranean spring bloom. The areal concentration of chl a integrated between 0 and $100 \mathrm{~m}$ was $107 \pm 24 \mathrm{mg} \mathrm{m}^{-2}$. CHEMTAX analysis revealed that this phytoplankton was dominated by Bacillariophyceae, with a significant contribution of Prasinophyceae (Table 2). The prevalent Bacillariophyceae analyzed by microscopy were Pseudo-nitzschia spp., Chaetoceros subgenus Hyalochaete spp., Thalassiosira spp., Guinardia delicatula, Bacteriastrum delicatulum, and Ditylum brightwellii. None of these genera or species are known for abnormal pigmentation, at least for the set of pigments considered as group markers in the present study.

Bacillariophyceae practically disappeared in the post-bloom period and the areal concentration of chl a was reduced to $28 \pm 7.1 \mathrm{mg} \mathrm{m}^{-2}$ (Table 2). There was a very clear segregation in the water column (Fig. 5), with Synechococcus spp. dominating at the surface (40\% chl a) and Prymnesiophyceae in the DCM (40 to $50 \% \mathrm{chl}$ a). Other significant groups were Prasinophyceae and Pelagophyceae in the DCM and Prymnesiophyceae at the surface.

The most significant change observed during the stratification period was the presence of Prochlorococcus spp., mainly in the DCM (Fig. 5). The contribution

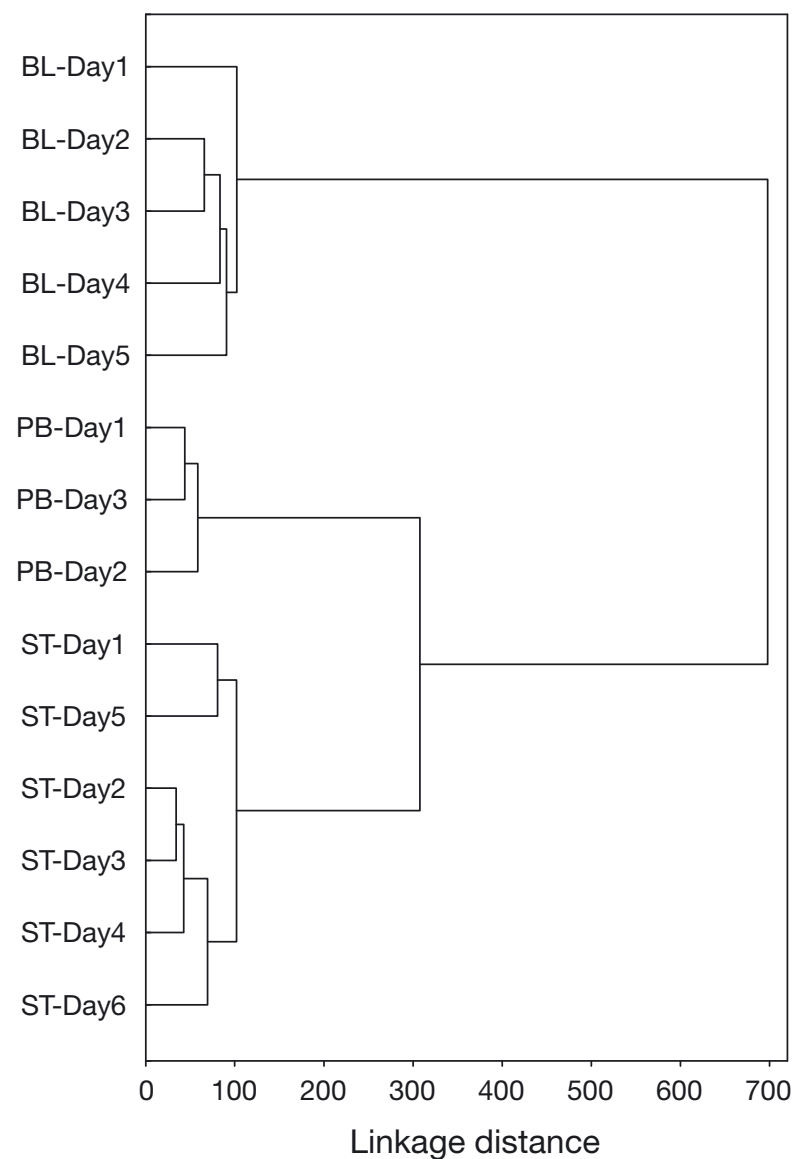

Fig. 4. Classification of the stations by cluster analysis according to their pigment characteristics. BL, PB, and ST indicate spring bloom, post-bloom, and late stratification periods, respectively

of eukaryotes diminished from 91 to $67 \%$ of total chl a biomass. Synechococcus spp., Prymnesiophyceae, and Prasinophyceae constituted most of the phytoplankton at the surface, and Prymnesiophyceae, Prochlorococ- 
Table 2. Areal chl a concentration $\left(\mathrm{mg} \mathrm{m}^{-2}\right)$ of the different phytoplankton groups integrated for the upper $100 \mathrm{~m}$. Percent contribution to the total chl $\mathrm{a}$ is shown in parenthesis. The computed error is the SD. bd: below detection

\begin{tabular}{|lccc|}
\hline & $\begin{array}{c}\text { Bloom } \\
(\mathrm{n}=5)\end{array}$ & $\begin{array}{c}\text { Post-bloom } \\
(\mathrm{n}=3)\end{array}$ & $\begin{array}{c}\text { Stratification } \\
(\mathrm{n}=6)\end{array}$ \\
\hline Total phytoplankton & $107 \pm 24$ & $28.4 \pm 7.1$ & $24.3 \pm 6.2$ \\
Synechococcus & $6.02 \pm 2.03(5.6)$ & $2.6 \pm 0.5(9.1)$ & $2.4 \pm 0.6(9.9)$ \\
Prochlorococcus & $\mathrm{bd}$ & $\mathrm{bd}$ & $5.5 \pm 1.5(22.5)$ \\
Bacillariophyceae & $73.7 \pm 18.7(69)$ & $1.0 \pm 0.4(3.5)$ & $0.87 \pm 0.26(3.6)$ \\
Prymnesiophyceae & $5.6 \pm 2.4(4.8)$ & $11.7 \pm 2.7(41.2)$ & $8.5 \pm 2.3(35.0)$ \\
Prasinophyceae & $12.4 \pm 5.0(11.8)$ & $5.6 \pm 1.7(19.6)$ & $0.77 \pm 0.28(3.2)$ \\
Pelagophyceae & $3.1 \pm 0.4(2.8)$ & $4.2 \pm 1.1(14.8)$ & $3.8 \pm 1.0(15.5)$ \\
Cryptophyceae & $3.2 \pm 0.6(2.9)$ & $2.7 \pm 0.7(9.5)$ & $1.6 \pm 0.5(6.4)$ \\
Dinophyceae & $3.5 \pm 0.6(3.21)$ & $0.69 \pm 0.23(2.4)$ & $0.96 \pm 0.36(3.9)$ \\
\hline
\end{tabular}

In summary, at the surface, Bacillariophyceae dominated during the bloom, and Prymnesiophyceae and Synechococcus spp. during the post-bloom and stratification periods. There was a clear vertical segregation within the prokaryotes, with Synechococcus spp. occupying always the shallower layers and Prochlorococcus spp. occupying the DCM during the stratification period. The vertical segregation was also evident in some eukaryotic groups e.g. Pelagophyceae, Prymnesiophyceae, and Cryptophyceae were more abundant in the DCM layer. cus spp., and Pelagophyceae in the DCM. Microscope observations confirmed the scarcity of large diatoms and the dominance of coccolithophores and dinoflagellates in the microplanktonic $(>10 \mu \mathrm{m})$ fraction during the post-bloom and stratification periods. Some of these dinoflagellates belonged to the genus Karenia. Species of this genus are known to form coastal blooms and can present Prymnesiophyceae-type pigmentation (Jeffrey \& Wright 2006). The possible pigment contribution of these dinoflagellates to the Prymnesiophyceae pigment pool was minor because Prymnesiophyceae-pigmented cells larger than $5 \mu \mathrm{m}$, the size fraction potentially contributed by Karenia spp., contributed $15 \%$ to the total Prymnesiophyceae pool (data not shown).

\section{Diversity}

The diversity index reflected the diversity that can be observed in Fig. 5. The Shannon index $\left(H^{\prime}\right)$ and the evenness in the distribution of the existing groups $\left(H^{\prime}: H^{\prime}{ }_{\max }\right)$ reflected the overwhelming dominance of Bacillariophyceae in the DCM during the bloom, with the lowest diversity values in terms of pigment groups (Table 3).

\section{TPI}

TPI was calculated from data presented in Table 4. A cluster analysis of the TPI values (City-block distances,

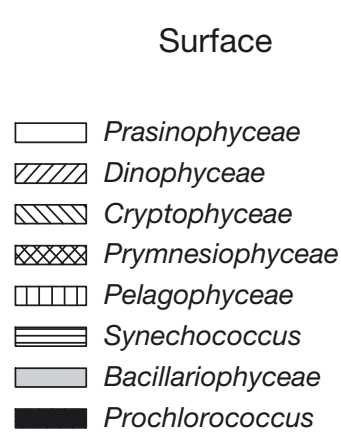

DCM
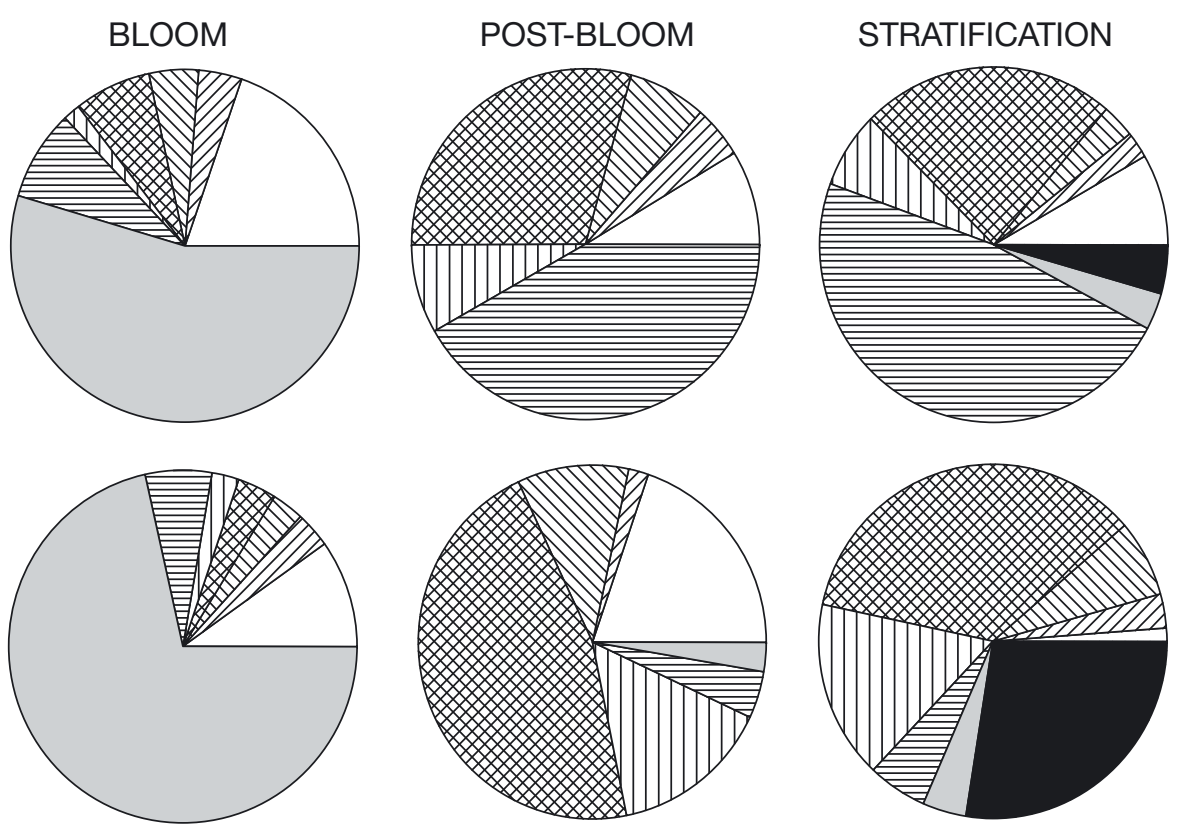

Fig. 5. Relative contribution of each phytoplankton group at the surface (0 to $5 \mathrm{~m} \mathrm{depth}$ ) and in the deep chlorophyll maximum (DCM) during the bloom, post-bloom, and stratification periods 
Ward's linkage method) distinguished 3 main assemblages of phytoplankton groups according to their trophic preferences (Fig. 6). Bacillariophyceae, Prasinophyceae, Dinophyceae, and Cryptophyceae can be considered to be the most eutrophic groups; Prymnesiophyceae, Pelagophyceae, and Synechococcus spp. the mesotrophic groups; and Prochlorococcus spp. the most oligotrophic group.

The data from Table 4 also allows us to validate the coherence of our results. The ratio PON:chl a (w:w) was 21, 103, and 71 for the bloom, post-bloom, and stratification periods, respectively. Assuming a Redfield $\mathrm{C}: \mathrm{N}$ ratio of 5.7 by weight (= 6.6 by mol), the corresponding particulate organic carbon (POC):chl a ratios are 120,584, and 406 respectively for the very surface waters. In parallel studies in the same layer we estimated phytoplankton carbon (PhytoC) to chl a ratios of 34 and 168 from dilution experiments for bloom and post-bloom periods, respectively (Gutiérrez-Rodríguez et al. 2010), and of 101 from microscopy for the stratification period. By comparing POC:chl $a$ and PhytoC:chl $a_{1}$ it can be deduced that phytoplankton made up 28, 29 , and $25 \%$ of POC during the bloom, post-bloom, and stratification periods, respectively. Gasol et al. (1997) presented an average ratio of autotrophic to total living carbon excluding detritus of $28 \%$ for oceanic waters.

\section{DISCUSSION}

Our objective was to unveil the preferences of different class-level phytoplankton groups in the open sea for waters with different degree of productivity (trophy). This information should provide clues about the ecological characteristics of these groups and, in turn, they could become ecological indicators of ecosystem status. Phytoplankton pigment distribution could clearly discriminate the bloom, post-bloom, and stratification periods, with bloom as the most distinct one (Fig. 4). The same discriminating pattern was shown by the distribution of nutrients, a consequence of biological (consumption) and physical (mixing) processes (Fig. 3). On the other hand, the stability of the water column presented the stratification period as the most distinct situation (Fig. 2). As expected, the transition from mixing to weak stratification induced a stronger response in phytoplankton populations and nutrient availability, than the progression of stability from postbloom to a much more stratified situation during the stratification period. The non-linear response of the biology to physical changes complicates the establishment of straightforward relationships. Our results confirm a general vision summarized by Cullen et al. (2002) in which changes of phytoplankton community

Table 3. Pigment group diversity and evenness as expressed by the Shannon index $\left(H^{\prime}\right)$ and evenness $\left(H^{\prime}: H^{\prime}{ }_{\max }\right)$. Errors represent SD. Only the data from the deep chlorophyll maximum (DCM) in the bloom period was significantly different from the other situations and depths ( $\mathrm{p}<0.05$, Bonferroni post hoc test)

\begin{tabular}{|c|c|c|c|c|c|c|}
\hline & \multicolumn{2}{|c|}{ Bloom $(n=5)$} & \multicolumn{2}{|c|}{ Post-bloom (n = 3) } & \multicolumn{2}{|c|}{ Stratification $(\mathrm{n}=6)$} \\
\hline & $H^{\prime}$ & $H^{\prime}: H_{\max }^{\prime}$ & $H^{\prime}$ & $H^{\prime}: H_{\max }^{\prime}$ & $H^{\prime}$ & $H^{\prime}: H_{\max }^{\prime}$ \\
\hline Surface & $1.37 \pm 0.26$ & $0.70 \pm 0.13$ & $1.46 \pm 0.06$ & $0.75 \pm 0.03$ & $1.46 \pm 0.10$ & $0.72 \pm 0.03$ \\
\hline DCM & $0.93 \pm 0.20$ & $0.47 \pm 0.10$ & $1.50 \pm 0.01$ & $0.77 \pm 0.01$ & $1.64 \pm 0.05$ & $0.79 \pm 0.02$ \\
\hline
\end{tabular}

Table 4. Distribution of phytoplankton groups at the surface, as the chl a concentration assigned by CHEMTAX, and of particulate organic nitrogen (PON), for each station. $\mathrm{BL}, \mathrm{PB}$, and $\mathrm{ST}$ indicate bloom, post-bloom, and stratification periods, respectively. bd: below detection

\begin{tabular}{|c|c|c|c|c|c|c|c|c|c|}
\hline \multirow[t]{2}{*}{ Stn } & \multicolumn{8}{|c|}{$\mathrm{Chl} a\left(\mathrm{ng} \mathrm{l}^{-1}\right)$} & \multirow[t]{2}{*}{ PON $\left(\mu g l^{-1}\right)$} \\
\hline & $\begin{array}{c}\text { Synecho- } \\
\text { coccus spp. }\end{array}$ & $\begin{array}{l}\text { Prochloro- } \\
\text { coccus spp. }\end{array}$ & $\begin{array}{l}\text { Bacillario- } \\
\text { phyceae }\end{array}$ & $\begin{array}{c}\text { Prymnesio- } \\
\text { phyceae }\end{array}$ & $\begin{array}{l}\text { Prasino- } \\
\text { phyceae }\end{array}$ & $\begin{array}{l}\text { Pelago- } \\
\text { phyceae }\end{array}$ & $\begin{array}{l}\text { Crypto- } \\
\text { phyceae }\end{array}$ & $\begin{array}{c}\text { Dino- } \\
\text { phyceae }\end{array}$ & \\
\hline BL-Day1 & 133 & bd & 1327 & 86.2 & 477 & 28.1 & 86.4 & 110 & 54.5 \\
\hline BL-Day2 & 160 & bd & 486 & 51.1 & 216 & 9.14 & 36.2 & 15.0 & 32.5 \\
\hline BL-Day3 & 76.1 & bd & 190 & 74.8 & 122 & 13.2 & 48.1 & 30.9 & 7.7 \\
\hline BL-Day4 & 17.8 & bd & 429 & 32.2 & 76.5 & 9.14 & 12.8 & 18.4 & 11.8 \\
\hline BL-Day5 & 37.4 & bd & 366 & 122 & 122 & 21.7 & 51.6 & 32.1 & 10.7 \\
\hline PB-Day1 & 32.5 & bd & bd & 14.5 & 7.82 & 4.39 & 4.26 & 3.39 & 7.7 \\
\hline PB-Day2 & 35.0 & bd & bd & 26.0 & 7.26 & 4.07 & 5.30 & 3.84 & 8.26 \\
\hline PB-Day3 & 29.7 & bd & bd & 27.6 & 5.29 & 10.6 & 7.26 & 4.00 & 7.7 \\
\hline ST-Day1 & 22.2 & $\mathrm{bd}$ & bd & 14.2 & 5.39 & 5.83 & 0.61 & 0.64 & 5.74 \\
\hline ST-Day3 & 43.4 & 5.22 & 1.01 & 16.1 & 6.51 & 4.19 & 2.30 & 2.53 & 5.32 \\
\hline ST-Day4 & 42.4 & 3.13 & 6.53 & 30.4 & 8.43 & 8.23 & 6.61 & 0.59 & 5.32 \\
\hline ST-Day6 & 43.2 & 5.73 & 3.06 & 14.2 & 5.99 & 3.63 & 0.26 & 3.97 & 4.2 \\
\hline
\end{tabular}


Group-specific Trophic Preference Index
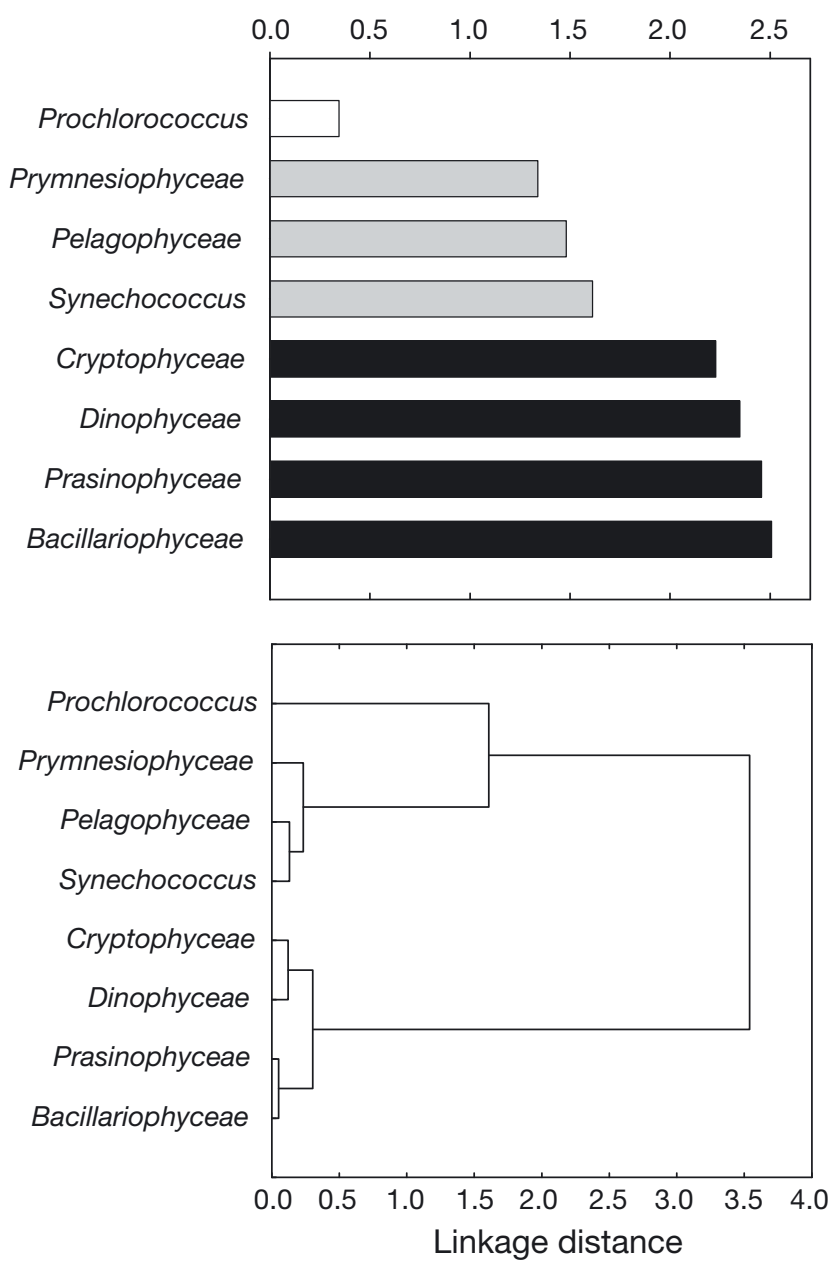

Fig. 6. Group-specific trophic preference index (TPI) for each phytoplankton group (upper panel). Black, gray, and white represent eutrophic, mesotrophic, and oligotrophic groups, respectively, as grouped by cluster analysis (lower panel) according to their TPI values

structure are mostly determined by the strong changes in the physical environment from mixing to stratification (bloom to post-bloom), and by biological interactions in low-nutrient regimes (from the post-bloom to the stratification period).

Combining the information derived from pigment analyses, flow cytometry, and microscopy, we distinguished the presence of 8 main phytoplankton groups: Prochlorococcus spp., Synechococcus spp., Prasinophyceae, Pelagophyceae, Prymnesiophyceae, Cryptophyceae, Dinophyceae, and Bacillariophyceae. Their distribution during the 3 contrasting situations (bloom, post-bloom, and stratification) should provide information about the groups' trophic and ecological preferences.

The physical, chemical, and biological conditions during the bloom can be considered typical, with low stratification, high nutrient levels, and high chl a concentrations (Figs. $2 \& 3$ ). Eukaryotic algae, and specifically Bacillariophyceae, dominated the phytoplankton community. Prochlorococcus spp. were absent, showing the typical exclusion of these 2 groups (Latasa \& Bidigare 1998). During the post-bloom, the stratification of the water column had increased, inorganic nutrients had nearly disappeared from the euphotic zone, and the DCM had deepened considerably from ca. $20 \mathrm{~m}$ to ca. $50 \mathrm{~m}$. The phytoplankton community was dominated by Prymnesiophyceae, with a significant contribution of Synechococcus spp. in the upper layers (Table 2, Fig. 5). During the stratification period, the water column was very stable, inorganic nutrients were negligible in the euphotic zone, and the DCM had deepened to $70 \mathrm{~m}$ (Figs. 1 \& 2). Prymnesiophyceae were still the dominant phytoplankton group but there was a substantial presence of Synechococcus spp. in the upper layers and Prochlorococcus spp. in the deep ones (Table 2, Fig. 5).

Trophic status is a loose and often subjective definition of ecosystem condition. Several indices have been proposed to quantitatively describe the trophic condition of water (Vollenweider et al. 1998 and references therein). The current trophic indexes reflect the biomass or the potential to form biomass and they include particulate and/or dissolved nutrients and some of them also include chlorophyll. According to Vollenweider et al. (1998), the most desirable parameters to be included in a trophic index are total nitrogen (TN) and total phosphorus (TP). This idea assumes that dissolved nitrogen and phosphorus could potentially be incorporated into biomass. However, waters with high TN and TP but low biomass because of light limitation such as those during winter in non-tropical areas or below the chlorophyll maximum cannot be considered eutrophic. High-nutrient, low-chlorophyll areas where iron and/or light are the limiting elements but TN and TP are very high, mostly in their dissolved form, cannot be considered eutrophic either. We think that the above-cited examples are significant exceptions that preclude the inclusion of dissolved forms in trophic indices. On the other hand, particulate organic phosphorus could be used as representative of trophic status. However, phosphorus is known to be stored and taken up by organisms in a disproportionate form (luxury uptake, Riegman et al. 2000). We maintain that $\mathrm{PON}$ is a straightforward indicator of trophic condition because it provides a good estimate of the nourishing (trophic) component, including both autotrophic and heterotrophic organisms.

In open sea and areas away from terrestrial influence, surface layers experience the highest changes in nutrient regimes in the water column. Therefore, the dynamics of the phytoplankton populations here 
should provide the best indication of the trophic preferences of the difference groups. Changes in the phytoplankton community of the DCM were difficult to relate to trophic preferences because the nutricline coincided with the DCM in all 3 situations (bloom, post-bloom, and stratification). Dynamics of nutrient availability in this layer depended on the vertical diffusivity from below, a complex process that could not be quantified during the present study. Thus, we will focus on the distribution of the different phytoplankton groups in the surface layer to tease out their trophic preferences. The group-specific TPI represents the mean PON concentration weighted for the biomass of each group (Fig. 6). The index distinguished 3 assemblages of phytoplankton groups according to their trophic preferences. Bacillariophyceae, Prasinophyceae, Dinophyceae, and Cryptophyceae can be considered the most eutrophic groups, with a clear preference for bloom conditions. The mesotrophic groups include Prymnesiophyceae, Pelagophyceae, and Synechococcus spp. They were more abundant during the bloom period but maintained a significant presence during both eutrophic and oligotrophic conditions. Prochlorococcus spp. clearly distinguish themselves as the most oligotrophic group, only present under the most oligotrophic conditions found. A comparison of this classification and the distribution of phytoplankton groups in different environments as reported in the literature is detailed next.

\section{The eutrophic groups}

Bacillariophyceae are the epitome of eutrophic conditions and are responsible for most blooms worldwide (Sarthou et al. 2005), but they can also play an important biogeochemical role in oligotrophic oceans (Scharek et al. 1999). Bacillariophyceae have been well studied and they responded as expected, dominating during the bloom period and being almost absent in the post-bloom and stratification periods. Dinophyceae, a eutrophic group according to our classification, have been reported under a large range of trophic conditions. They form blooms in estuaries and near-shore regions around the world (Litaker et al. 2002) and are typically responsible for harmful algal blooms (Hallegraeff 1993). They are also seen in coastal areas as typical of stable, oligotrophic conditions occurring at the end of the succession (Margalef 1978). In the open ocean, however, pigments of autotrophic Dinophyceae have seldom been reported as significant (Llewellyn et al. 2005) and the predominant forms observed under the microscope have been suggested to be heterotrophic, at least under oligotrophic conditions (Latasa et al. 1992). Our results indicate a residual presence of
Dinophyceae during bloom and post-bloom conditions, similar to the last stages of the North Atlantic bloom (Barlow et al. 1993). On the other hand, Mackey et al. (2002) found an increase in their contribution to phytoplankton biomass under natural nutrient enrichment conditions in the equatorial Pacific. In terms of vertical distribution, Dinophyceae seem to contribute more in surface populations (Fig. 5), in agreement with Qian et al. (2003). It seems, therefore, that in the open ocean, Dinophyceae could play a role of secondary importance in surface waters in the late stages of bloom and post-bloom conditions.

Cryptophyceae and Prasinophyceae are the other 2 eutrophic groups in our study but with a significantly higher contribution of Prasinophyceae during the bloom period. The Cryptophyceae species described are mostly of nanoplanktonic size (2 to $20 \mu \mathrm{m}$ ) and represent the large-size fraction of the so-called small phytoplankton. It is assumed that small phytoplankton do not usually reach high concentrations because of high grazing rates and short generation times of their protozoan predators. Cryptophyceae cells at the high end of their size range could have the chance to escape protozoan predation and, therefore, are potential bloom formers. Indeed, Cryptophyceae blooms involve relatively large nanoplanktonic cells. Cryptophyceae blooms have been reported in Antarctica (Rodriguez et al. 2002), especially in retreating ice-edge and glacial melt-waters with reduced salinities (Buma et al. 1992, Moline et al. 2004), and in fjords (Haigh et al. 1992). There is not a clear ecological explanation for this specific low-salinity niche, and physiological studies relating Cryptophyceae and salinity are absent to our knowledge. Mesodinium rubrum, a ciliate with Cryptophyceae endosymbionts, is also capable of forming blooms (Gieskes \& Kraay 1983). In our study, Cryptophyceae were always a small portion of the phytoplankton $(<10 \%)$, with a larger relative contribution in the DCM than at the surface (Fig. 5). They were outnumbered during bloom conditions by groups that were classified as less eutrophic according to our classification (Prymnesiophyceae and Synechococcus spp.). Marty et al. (2002) found that Cryptophyceae and Bacillariophyceae peaked at the same time during a 7 yr study at the DYFAMED site and Vidussi et al. (2000) also reported a progressive decrease of Cryptophyceae towards oligotrophic conditions. Both studies were performed in the northwestern Mediterranean close to our study area. It can be summarized that although bloom conditions seem to favor the presence of Cryptophyceae, open-sea conditions do not favor a strong proliferation of this group.

The inclusion of Prasinophyceae in the eutrophic group was initially unexpected. Except for some welldescribed genera (e.g. Pyramimonas and Tetraselmis), 
Prasinophyceae cells that dominate in marine environments are usually included in the picoplankton range. It is thus assumed that their concentration will be kept low by protozoan grazing. However, Prasinophyceae was the most abundant group, after Bacillariophyceae, during the bloom period (Table 2). It has been suggested that Prasinophyceae are most numerous in coastal waters and relatively absent from oceanic regimes (Thomsen \& Buck 1998, Not et al. 2005). However, there are several reports of important contribution of Prasinophyceae in Arctic (Obayashi et al. 2001, Hill et al. 2005) and Antarctic areas (Peeken 1997, Van Leeuwe et al. 1998), and Higgins \& Mackey (2000) found that chlorophytes, which include Prasinophyceae, increased in upwelling conditions south of the western equatorial Pacific. From these and our results, it can be deduced that Prasinophyceae seem to prefer eutrophic conditions. The fact that Prasinophyceae of picoplankton size with a clear preference for nutrient-rich conditions do not make regular blooms would be a clear example of protozoan grazing control over a group with a considerable potential for bloom formation.

\section{The mesotrophic group}

Prymnesiophyceae were dominant during nonbloom conditions. This observation has been repeated almost everywhere, including in our study area (Latasa et al. 1992, Barlow et al. 1997, Vidussi et al. 2000). The reasons for the cosmopolitanism of the Prymnesiophyceae in marine systems are difficult to unveil. One explanation could be that, as for Dinophyceae, the physiological diversity of this group might be very large. In fact, some species/genera of Prymnesiophyceae are involved in key biogeochemical processes (calcification by coccolithophores or DMS production by Phaeocystis spp.). Prymnesiophyceae blooms are mainly formed by the genera Phaeocystis or Emiliania with a worldwide distribution (Tyrrell \& Merico 2004, Schoemann et al. 2005). On the other hand, pigmentbased studies have always shown Prymnesiophyceae as a main group in oligotrophic waters, where picoplankton is the dominant fraction. Paradoxically, to our knowledge, there are only 2 Prymnesiophyceae species described with a mean size $<3 \mu \mathrm{m}$ (Vaulot et al. 2008). Molecular techniques have confirmed the presence of Prymnesiophyceae in the picoplankton range but not their high abundances (Moon-van der Staay et al. 2000). Currently, there is an open debate about this discrepancy and the likely explanations (Not et al. 2008) but refined molecular techniques appear to confirm the important contribution of Prymnesiophyceae to the picophytoplankton (Liu et al. 2009). In any case, in the present study, Prymnesiophyceae pigment contribution was maximum during the post-bloom, both in absolute and relative terms (Table 2). This predominance was clearer in the DCM than at the surface, mainly because of the increasing contribution of Synechococcus spp. in this latter layer (Fig. 5). Our results indicate that Prymnesiophyceae thrive quite well in oligotrophic and DCM conditions but they start to be outcompeted by cyanobacteria when oligotrophy becomes more acute.

In many pigment studies, Pelagophyceae are referred to as Chrysophyceae. Two Pelagophyceae species, Aureoumbra lagunensis and Aureococcus anophagefferens, were responsible for nuisance brown tide blooms with occasional economic damages (DeYoe et al. 1997, Laroche et al. 1997). However, Pelagophyceae are not dominant in open-sea ecosystems and their role is unknown. It should be noted that a naked, picoplanktonic Dictyochophyceae has been shown to contain the pigment suite typical of Pelagophyceae (Eikrem et al. 2004). If present, it would have been included in our algal class. Pelagophyceae species are in the picoplankton size range (Andersen et al. 1993) and have been shown to prefer deep waters (Gieskes et al. 1988, Furuya et al. 2003) although there are also a few reports with the opposite observations (Riegman \& Kraay 2001). Our results confirm the relative unresponsiveness of this group to different trophic conditions and their preference for the DCM (Fig. 5). The combination of these 2 observations leads to the conclusion that the preference of this group for deep environments is not a response to the higher nutrient levels there but more likely to decreased irradiance conditions.

The relatively easy quantification of Synechococcus spp. and Prochlorococcus spp. by flow cytometry has placed these 2 cyanobacteria among the best-studied groups of the phytoplankton (Partensky et al. 1999a). In spite of their relatively similar size and same phylogenetic affiliation there are profound differences in their physiology and ecology (Partensky et al. 1999a, Moore et al. 2002). Based on elemental composition, both have been suggested to have low requirements for phosphorus, the main limiting nutrient in the Mediterranean (Bertilsson et al. 2003), which might explain their increasing contribution with increasing oligotrophy (Table 2). However, Synechococcus spp. abundance was maximum during bloom conditions. Lindell \& Post (1995) also reported that Synechococcus spp. was the major component of the ultraphytoplankton $(<5 \mu \mathrm{m})$ during a spring bloom, while Prochlorococcus spp. dominated nutrient-depleted summerstratified waters. Other studies have demonstrated a decreasing importance of Synechococcus spp. as surface waters become depleted in nutrients (Partensky et 
al.1999a,b, Tarran et al. 1999, Mackey et al. 2002), confirming the preference of Synechococcus spp. for more eutrophic conditions. In this sense, the reasons for the lack of Synechococcus spp. blooms (but see Bidigare et al. 1997, Morel 1997 for exceptions) under nutrientreplete conditions could be attributed to protozoan grazing, as in the case of Prasinophyceae. The significant presence of Synechococcus spp. under oligotrophic conditions indicates that this group is extremely flexible in terms of nutrient requirements. The only environment from where Synechococcus spp. appear to be excluded is under low irradiance: in the DCM, Synechococcus spp. seem to be rapidly outcompeted by eukaryotes and Prochlorococcus spp.

\section{The oligotrophic group}

Prochlorococcus spp. are the picoplanktonic phytoplankton epitome of ultraoligotrophic conditions. Prochlorococcus spp. populations are known to decline north of $45^{\circ} \mathrm{N}$, due to lower seawater temperatures (Partensky et al. 1999b). They dominate the subtropical gyres (Ondrusek et al. 1991, Zubkov et al. 2000, Gibb et al. 2001) and have been found in the Mediterranean (Vaulot et al. 1990, Barlow et al. 1997). We found a substantial presence of Prochlorococcus spp. in the DCM with a lower contribution at the surface during the most oligotrophic situation. This vertical segregation of Synechococcus spp. at the surface and Prochlorococcus spp. in deep layers has been reported repeatedly using both flow cytometry (Veldhuis \& Kraay 1990, Campbell \& Vaulot 1993, Furuya et al. 2003) and pigment analysis (Bustillos-Guzmán et al. 1995, Higgins \& Mackey 2000). This situation is interpreted to be typical of winter-mixing areas, like our study site, where there is not enough time between the end of the spring bloom and the next winter mixing event for a Prochlorococcus spp. population to fully recolonize the oligotrophic surface layer (Partensky et al. 1999b). Our study area is one of the nutrient-rich regions of the Mediterranean (Bosc et al. 2004) and the oligotrophic conditions are not so extreme as in the eastern Mediterranean or the subtropical gyres, where Prochlorococcus spp. are dominant also in surface waters (Partensky et al. 1996, Zubkov et al. 2000). For us, the dominance of Prochlorococcus spp. in the DCM is rather puzzling. In theory, diffusivity from below makes the DCM the most nutrient-rich layer of the euphotic zone during the stratification period. Why then does Prochlorococcus spp., a strictly nutrient-poor organism, thrive in such an environment? One explanation could be that the Mediterranean strains in our study area are more sensitive to UV radiation and are suppressed from surface waters (Sommaruga et al. 2005).
Diversity estimated from pigment groups will always be relatively low because of the low number of groups that can be distinguished by this technique. Still, the relative comparison among the 3 situations showed that, as expected, communities developed in stratified, nutrient-poor environments (post-bloom and stratification) presented higher diversity and evenness that populations of nutrient-rich bloom conditions (Table 3).

\section{CONCLUSIONS}

We have focused on a bottom-up perspective of the factors regulating the distribution of phytoplankton groups in 3 trophic situations. We have also proposed an index to classify phytoplankton groups according to their tropic preferences and label them as oligotrophic, mesotrophic, or eutrophic. The results obtained in the present study confirm existing concepts of the trophic preferences of some phytoplankton groups and provide new insights into the ecology of less-studied ones. Thus, the topical adscription of Bacillariophyceae to eutrophy and Prochlorococcus spp. to oligotrophy is confirmed. The clear differentiation of Prochlorococcus spp. and Synechococcus spp., with the latter group being less oligotrophic, was also confirmed. The background role of Prymnesiophyceae and Pelagophyceae throughout different trophic conditions, with a preference of the latter group for deeper layers, is also confirmed. The most novel information is from the groups we labeled eutrophic. Thus, it was unexpected that Prasinophyceae of typically picoplanktonic size showed a clear preference for bloom conditions and were outnumbered by larger cells (Prymnesiophyceae) in nutrient-poor waters, an observation opposite to the expected size distribution under nutrient limitation. We expected that Cryptophyceae could thrive in bloom conditions because they seem to prefer coastal areas (generally more eutrophic than open ocean), sometimes forming blooms (Novarino 2003). However, Cryptophyceae abundance was very low. Based on a review of the literature, we hypothesize that Cryptophyceae may prefer or may outcompete other species under the decreased salinity conditions in coastal areas relative to the open ocean. Finally, the inclusion of Dinophyceae in the eutrophic group reflects the wide range of trophic conditions where this group can thrive.

It must be clearly stated that the trophic preferences of each group are not necessarily related to their contribution in the different trophic phases. Thus, Prymnesiophyceae, Pelagophyceae, and Synechococcus spp. (mesotrophic) were more abundant than Cryptophyceae (eutrophic) during the bloom period. How- 
ever, the mesotrophic groups were less sensitive to trophic changes than Cryptophyceae. One possible explanation for the presence of groups with wide trophic preferences is that there might be a succession from eutrophic to oligotrophic species (strains in the case of Synechococcus spp.) within those groups. Indeed, the distinction of algal groups provides a basic discrimination of their trophic characteristics because they may include a large number of species. On the other hand, species belonging to each group share a common phylogenetic evolution that provides clues of their initial ecophysiological characteristics that have been preserved through history (Quigg et al. 2003, Finkel et al. 2007). The knowledge of those traits has been useful for tracking the environmental conditions in the paleorecord (Katz et al. 2004, Falkowski \& Oliver 2007) and should be useful again for predicting future diversity scenarios in the framework of global change.

Acknowledgements. Funding for this study was provided by research grants from the Spanish Ministry of Education and Science (REN2002-04151-C02-01/MAR， REN2002-10809E/MAR, and REN-2002-10718-E/MAR) and Generalitat of Catalunya (2002PIRA00297). We are grateful to the captains and crews of RVs 'García del Cid' and 'Cornide de Saavedra' and colleagues on board for their invaluable help and great atmosphere shared during the cruises. C. Cardelús collected and analyzed the flow cytometry samples. We thank S. Wright for graciously providing a user-friendly version of CHEMTAX (v. 1.95), B. Molí for technical help with the pigment analyses, and G. Gónzalez-Nuevo for his suggestions. Four reviewers made valuable suggestions for improving the manuscript. This work has been carried out under the framework of the Convenio de Colaboración between the IEO and the ICM-CSIC.

\section{LITERATURE CITED}

Andersen RAG, Saunders W, Paskind MP, Sexton JP (1993) Ultrastructure and 18S rRNA gene sequence for Pelagomonas calceolata gen. et sp. nov. and the description of a new algal class, the Pelagophyceae classis nov. J Phycol 29:701-715

Andersen R, Bidigare R, Keller M, Latasa M (1996) A comparison of HPLC pigment signatures and electron microscopic observations for oligotrophic waters of the North Atlantic and Pacific Oceans. Deep-Sea Res II 43:517-537

Barlow RG, Mantoura RFC, Gough MA, Fileman TW (1993) Pigment signatures of the phytoplankton composition in the Northeastern Atlantic during the 1990 spring bloom. Deep-Sea Res II 40:459-477

Barlow RG, Mantoura RFC, Cummings DG, Fileman TW (1997) Pigment chemotaxonomic distributions of phytoplankton during summer in the Western Mediterranean. Deep-Sea Res II 44:833-850

Bertilsson O, Berglund O, Karl DM, Chisholm SW (2003) Elemental composition of marine Prochlorococcus and Synechococcus: implications for the ecological stoichiometry of the sea. Limnol Oceanogr 48:1721-1731

Bidigare RR, Latasa M, Johnson Z, Barber RT, Trees CC, Balch WM (1997) Observations of a Synechococcus- dominated cyclonic eddy in open-oceanic waters of the Arabian Sea. Proc SPIE 2963:260-265

Bosc E, Bricaud A, Antoine D (2004) Seasonal and interannual variability in algal biomass and primary production in the Mediterranean Sea, as derived from 4 years of SeaWiFS observations. Global Biogeochem Cycles 18:GB1005 doi:10.1029/2003GB002034

Buma AGJ, Gieskes WWC, Thomsen HA (1992) Abundance of Cryptophyceae and chlorophyll $b$-containing organisms in the Weddell-Scotia Confluence area in the spring of 1988. Polar Biol 12:43-52

Bustillos-Guzmán J, Claustre H, Marty JC (1995) Specific phytoplankton signatures and their relationship to hydrographic conditions in the coastal northwestern Mediterranean Sea. Mar Ecol Prog Ser 124:247-258

Cailliau C, Claustre H, Vidussi F, Marie D, Vaulot D (1996) Carbon biomass, and gross growth rates as estimated from ${ }^{14} \mathrm{C}$ pigment labelling, during photoacclimation in Prochlorococcus CCMP 1378. Mar Ecol Prog Ser 145:209-221

> Campbell L, Vaulot D (1993) Photosynthetic picoplankton community structure in the subtropical North Pacific Ocean near Hawaii (station ALOHA). Deep-Sea Res I 40: 2043-2060

Carlson RE (1977) A trophic state index for lakes. Limnol Oceanogr 22:361-369

Cullen JJ, Franks PJS, Karl DM, Longhurst A (2002) Physical influences on marine ecosystem dynamics. In: Robinson AR, McCarthy JJ, Rothschild BJ (eds) Biological-physical interactions in the sea. The sea, Vol 12. Wiley, New York, NY, p 297-336

D'Ortenzio F, Ribera d'Alcalà M (2009) On the trophic regimes of the Mediterranean Sea: a satellite analysis. Biogeosciences 6:139-148

> DeYoe H, Stockwell D, Bidigare R, Latasa M, Johnson P, Hargraves P, Suttle C (1997) Description and characterization of the algal species Aureoumbra lagunensis gen. et sp. nov. and referral of Aureoumbra and Aureococcus to the Pelagophyceae. J Phycol 33:1042-1048

Eikrem W, Romari K, Latasa M, Le Gall F, Throndsen J, Vaulot D (2004) Florenciella parvula gen. et sp. nov. (Dictyochophyceae, Heterokontophyta), a small flagellate isolated from the English Channel. Phycologia 43:658-668

Elster HJ (1958) Das limnologische Seetypensystem, Rückblick und Ausblick. Verh Internat Verein Limnol 13: 101-120

Falkowski PG, Oliver MJ (2007) Mix and match: how climate selects phytoplankton. Nat Rev Microbiol 5:813-819

Finkel ZV, Quigg AS, Chiampi RK, Schofield OE, Falkowski PG (2007) Phylogenetic diversity in cadmium: phosphorus ratio regulation by marine phytoplankton. Limnol Oceanogr 52:1131-1138

> Furuya K, Hayashi M, Yabushita Y, Ishikawa A (2003) Phytoplankton dynamics in the East China Sea in spring and summer as revealed by HPLC-derived pigment signatures. Deep-Sea Res II 50:367-387

Gasol JM, del Giorgio PA, Duarte CM (1997) Biomass distribution in marine planktonic communities. Limnol Oceanogr 42:1353-1363

Gibb SW, Cummings DG, Irigoien X, Barlow RG, Mantoura RFC (2001) Phytoplankton pigment chemotaxonomy of the Northeastern Atlantic. Deep-Sea Res II 48:795-823

Gieskes WWC, Kraay GW (1983) Dominance of Cryptophyceae during the phytoplankton spring bloom in the central North Sea detected by HPLC analysis of pigments. Mar Biol 75:179-185

Gieskes WWC, Kraay GW, Nontji A, Setiapermana D, Sutomo (1988) Monsoonal alternation of a mixed and a layered 
structure in the phytoplankton of the euphotic zone of the Banda Sea (Indonesia): a mathematical analysis of algal pigment fingerprints. Neth J Sea Res 22:123-137

Grasshoff K, Ehrhardt M, Kremling K (1999) Methods of seawater analysis, 3rd edn. Verlag Chemie, Weinheim

Gutiérrez-Rodríguez A, Latasa M, Estrada M, Vidal M, Marrasé C (2010) Carbon fluxes through major phytoplankton groups during the spring bloom and post-bloom in the Northwestern Mediterranean Sea. Deep-Sea Res I 57:486-500

Haigh R, Taylor FJR, Sutherland TF (1992) Phytoplankton ecology of Sechelt Inlet, a fjord system of the British Columbia coast. 1. General features of the nanoplankton and microplankton. Mar Ecol Prog Ser 89:117-134

Hallegraeff GM (1993) A review of harmful algal blooms and their apparent global increase. Phycologia 32:79-99

> Higgins HW, Mackey DJ (2000) Algal class abundances, estimated from chlorophyll and carotenoid pigments, in the western Equatorial Pacific under El Niño and non-El Niño conditions. Deep-Sea Res I 47:1461-1483

Hill V, Cota G, Stockwell D (2005) Spring and summer phytoplankton communities in the Chukchi and Eastern Beaufort seas. Deep-Sea Res II 52:3369-3385

Jacquet S, Lennon JF, Marie D, Vaulot D (1998) Picoplankton population dynamics in coastal waters of the northwestern Mediterranean Sea. Limnol Oceanogr 43:1916-1931

Jeffrey SW, Wright SW (2006) Photosynthetic pigments in marine microalgae: insights from cultures and the sea. In: Subba Rao DV (ed) Algal cultures, analogues of blooms and applications. Science Publishers, Enfield, NH, p 33-90

Kana TM, Glibert PM (1987) Effect of irradiances up to $2000 \mu \mathrm{E} \mathrm{m}^{-2} \mathrm{~s}^{-1}$ on marine Synechococcus WH 7803. I. Growth, pigmentation, and cell composition. Deep-Sea Res A 34:479-495

Katz ME, Finkel ZV, Grzebyk D, Knoll AH, Falkowski PG (2004) Evolutionary trajectories and biogeochemical impacts of marine eukaryotic phytoplankton. Annu Rev Ecol Evol Syst 35:523-556

Laroche J, Nuzzi R, Waters R, Wyman K, Falkowski PG, Wallace DWR (1997) Brown tide blooms in Long Island's coastal waters linked to interannual variability in groundwater flow. Glob Change Biol 3:397-410

Latasa M (1995) Pigment composition of Heterocapsa sp. and Thalassiosira weissflogii growing in batch cultures under different irradiances. Sci Mar 59:25-37

Latasa M (2007) Improving estimations of phytoplankton class abundances using CHEMTAX. Mar Ecol Prog Ser 329: $13-21$

> Latasa M, Bidigare RR (1998) A comparison of phytoplankton populations of the Arabian Sea during the Spring Intermonsoon and Southwest Monsoon of 1995 as described by HPLC-analyzed pigments. Deep-Sea Res II 45:2133-2170

> Latasa M, Estrada M, Delgado M (1992) Plankton-pigment relationships in the northwestern Mediterranean during stratification. Mar Ecol Prog Ser 88:61-73

> Latasa M, van Lenning K, Garrido JL, Scharek R, Estrada M, Rodriguez F, Zapata M (2001) Losses of chlorophylls and carotenoids in aqueous acetone and methanol extracts prepared for RPHPLC analysis of pigments. Chromatographia 53:385-391

Le Quéré C, Harrison SP, Prentice IC, Buitenhuis ET and others (2005) Ecosystem dynamics based on plankton functional types for global ocean biogeochemistry models. Glob Change Biol 11:2016-2040 doi:10.1111/j.13652486.2005.1004.x

Legendre L, Rassoulzadegan F (1996) Food-web mediated export of biogenic carbon in oceans: hydrodynamic control. Mar Ecol Prog Ser 145:179-193
Levitus S (1982) Climatological atlas of the world ocean. NOAA Prof Pap 13. US Department of Commerce. Rockville, Madison

Lindell D, Post AF (1995) Ultraphytoplankton succession is triggered by deep winter mixing in the Gulf of Aqaba (Eilat), Red Sea. Limnol Oceanogr 40:1130-1141

> Litaker RW, Tester PA, Duke CS, Kenney BE, Pinckney JL, Ramus J (2002) Seasonal niche strategy of the bloomforming dinoflagellate Heterocapsa triquetra. Mar Ecol Prog Ser 232:45-62

> Liu H, Probert I, Uitz J, Claustre H and others (2009) Extreme diversity in non-calcifying haptophytes explains a major pigment paradox in open oceans. Proc Natl Acad Sci USA 106:12803-12808

> Llewellyn CA, Fishwick JR, Blackford JC (2005) Phytoplankton community assemblage in the English Channel: a comparison using chlorophyll a derived from HPLCCHEMTAX and carbon derived from microscopy cell counts. J Plankton Res 27:103-119

> López-Urrutia A, San Martin E, Harris RP, Irigoien X (2006) Scaling the metabolic balance of the oceans. Proc Natl Acad Sci USA 103:8739-8744

Mackey MD, Mackey DJ, Higgins HW, Wright SW (1996) CHEMTAX - a program for estimating class abundances from chemical markers: application to HPLC measurements of phytoplankton. Mar Ecol Prog Ser 144:265-283

> Mackey DJ, Blanchot J, Higgins HW, Neveux J (2002) Phytoplankton abundances and community structure in the equatorial Pacific. Deep-Sea Res II 49:2561-2582

Margalef R (1978) Life forms of phytoplankton as survival alternatives in an unstable environment. Oceanol Acta 1:493-509

Marty JC, Chiaverini J, Pizay MD, Avril B (2002) Seasonal and interannual dynamics of nutrients and phytoplankton pigments in the western Mediterranean Sea at the DYFAMED time-series station (1991-1999). Deep-Sea Res II 49:1965-1985

Moline MA, Claustre H, Frazer TK, Schofield O, Vernet M (2004) Alteration of the food web along the Antarctic peninsula in response to a regional warming trend. Glob Change Biol 10:1973-1980

Moon-van der Staay SY, van der Staay GWM, Guillou L, Vaulot D, Claustre H, Medlin LK (2000) Abundance and diversity of prymnesiophytes in the picoplankton community from the equatorial Pacific Ocean inferred from $18 \mathrm{~S}$ rDNA sequences. Limnol Oceanogr 45:98-109

Moore LR, Post AF, Rocap G, Chisholm SW (2002) Utilization of different nitrogen sources by the marine cyanobacteria Prochlorococcus and Synechococcus. Limnol Oceanogr 47:989-996

Morel A (1997) Consequences of a Synechococcus bloom upon the optical properties of oceanic (case 1) waters. Limnol Oceanogr 42:1746-1754

Not F, Massana R, Latasa M, Marie D and others (2005) Late summer community composition and abundance of photosynthetic picoeukaryotes in Norwegian and Barents Seas. Limnol Oceanogr 50:1677-1686

Not F, Latasa M, Scharek R, Viprey M and others (2008) Protistan assemblages across the Indian Ocean, with a specific emphasis on the picoeukaryotes. Deep-Sea Res I 55: 1456-1473

- Novarino G (2003) A companion to the identification of cryptomonad flagellates (Cryptophyceae = Cryptomonadea). Hydrobiologia 502:225-270

Obayashi Y, Tanoue E, Suzuki K, Handa N, Nojiri Y, Wong CS (2001) Spatial and temporal variabilities of phytoplankton community structure in the northern North Pacific as 
determined by phytoplankton pigments. Deep-Sea Res I 48:439-469

Olson RJ, Zettler ER, Durand MD (1993) Phytoplankton analysis using flow cytometry. In: Kemp PF, Sherr BF, Sherr EB, Cole JJ (eds) Handbook of methods in aquatic microbial ecology. Lewis Publishers, Boca Raton, FL, p 175-185

$>$ Ondrusek ME, Bidigare RR, Sweet ST, Defreitas DA, Brooks JM (1991) Distribution of phytoplankton pigments in the North Pacific Ocean in relation to physical and optical variability. Deep-Sea Res A 38:243-266

Partensky F, Blanchot J, Lantoine F, Neveux J, Marie D (1996) Vertical structure of picophytoplankton at different trophic sites of the tropical northeastern Atlantic Ocean. Deep-Sea Res I 43:1191-1213

Partensky F, Blanchot J, Vaulot D (1999a) Differential distribution and ecology of Prochlorococcus and Synechococcus in oceanic waters: a review. Bull Inst Oceanogr Monaco 19:457-475

Partensky F, Hess WR, Vaulot D (1999b) Prochlorococcus, a marine photosynthetic prokaryote of global significance. Microbiol Mol Biol Rev 63:106-127

Peeken I (1997) Photosynthetic pigment fingerprints as indicators of phytoplankton biomass and development in different water masses of the Southern Ocean during austral spring. Deep-Sea Res II 44:261-282

Qian YR, Jochens AE, Kennicutt MC, Biggs DC (2003) Spatial and temporal variability of phytoplankton biomass and community structure over the continental margin of the northeast Gulf of Mexico based on pigment analysis. Cont Shelf Res 23:1-17

Quigg A, Finkel ZV, Irwin AJ, Rosenthal Y and others (2003) The evolutionary inheritance of elemental stoichiometry in marine phytoplankton. Nature 425:291-294

Reynolds CS, Huszar V, Kruk C, Naselli-Flores L, Melo S (2002) Towards a functional classification of the freshwater phytoplankton. J Plankton Res 24:417-428

Riegman R, Kraay GW (2001) Phytoplankton community structure derived from HPLC analysis of pigments in the Faroe-Shetland Channel during summer 1999: the distribution of taxonomic groups in relation to physical/chemical conditions in the photic zone. J Plankton Res 23: 191-205

Riegman R, Stolte W, Noordeloos AAM, Slezak D (2000) Nutrient uptake and alkaline phosphatase (ec 3:1:3:1) activity of Emiliania huxleyi (Prymnesiophyceae) during growth under $\mathrm{N}$ and $\mathrm{P}$ limitation in continuous cultures. J Phycol 36:87-96

Rodriguez F, Varela M, Zapata M (2002) Phytoplankton assemblages in the Gerlache and Bransfield Straits (Antarctic Peninsula) determined by light microscopy and CHEMTAX analysis of HPLC pigment data. Deep-Sea Res II 49:723-747

Rusch DB, Halpern AL, Sutton G, Heidelberg KB and others (2007) The Sorcerer II global ocean sampling expedition: northwest Atlantic through eastern tropical Pacific. PLoS Biol 5:e77, doi:10.1371/journals.pbio.0050077

Sarthou G, Timmermans KR, Blain S, Treguer P (2005) Growth physiology and fate of diatoms in the ocean: a review. J Sea Res 53:25-42

Scharek R, Tupas LM, Karl DM (1999) Diatom fluxes to the deep sea in the oligotrophic North Pacific gyre at Station ALOHA. Mar Ecol Prog Ser 182:55-67

Editorial responsibility: Rodney Forster,

Lowestoft, UK
Schoemann V, Becquevort S, Stefels J, Rousseau W, Lancelot C (2005) Phaeocystis blooms in the global ocean and their controlling mechanisms: a review. J Sea Res 53:43-66

Sogin ML, Morrison HG, Huber JA, Welch DM and others (2006) Microbial diversity in the deep sea and the underexplored 'rare biosphere'. Proc Natl Acad Sci USA 103: $12115-12120$

Sommaruga R, Hofer JS, Alonso-Saez L, Gasol JM (2005) Differential sunlight sensitivity of picophytoplankton from surface Mediterranean coastal waters. Appl Environ Microbiol 71:2154-2157

Tarran GA, Burkill PH, Edwards ES, Woodward EMS (1999) Phytoplankton community structure in the Arabian Sea during and after the SW Monsoon, 1994. Deep-Sea Res II 46:655-676

Thienemann A (1928) Der Sauerstoff im eutrophen und oligotrophen See. Ein Beitrag zur Seetypenlehre. Die Binnengewässer 4. E. Schweizerbart'sche Verlagsbuchhandlung, Stuttgart

> Thomsen HA, Buck KR (1998) Nanoflagellates of the central California waters: taxonomy, biogeography and abundance of primitive, green flagellates (Pedinophyceae, Prasinophyceae). Deep-Sea Res II 45:1687-1707

Tyrrell T, Merico A (2004) Emiliania huxleyi: bloom observations and the conditions that induce them. In: Thierstein HR, Young JR (eds) Coccolithophores: from molecular processes to global impact. Springer-Verlag, Berlin, p 75-97

Van Leeuwe MA, De Baar HJW, Veldhuis MJW (1998) Pigment distribution in the Pacific region of the Southern Ocean (autumn 1995). Polar Biol 19:348-353

Vaulot D, Partensky F, Neveux J, Mantoura RFC, Llewellyn CA (1990) Winter presence of prochlorophytes in surface waters of the northwestern Mediterranean Sea. Limnol Oceanogr 35:1156-1164

> Vaulot D, Eikrem W, Viprey M, Moreau H (2008) The diversity of small eukaryotic phytoplankton $(\leq 3 \mu \mathrm{m})$ in marine ecosystems. FEMS Microbiol Rev 32:795-820

> Veldhuis MJW, Kraay GW (1990) Vertical distribution and pigment composition of a picoplanktonic prochlorophyte in the subtropical North Atlantic: a combined study of HPLC-analysis of pigments and flow cytometry. Mar Ecol Prog Ser 68:121-127

Vidussi F, Marty JC, Chiavérini J (2000) Phytoplankton pigment variations during the transition from spring bloom to oligotrophy in the northwestern Mediterranean Sea. Deep-Sea Res I 47:423-445

- Vollenweider RA, Giovanardi F, Montanari G, Rinaldi A (1998) Characterization of the trophic conditions of marine coastal waters with special reference to the NW Adriatic Sea: proposal for a trophic scale, turbidity and generalized water quality index. Environmetrics 9:329-357

Zapata M, Rodriguez F, Garrido JL (2000) Separation of chlorophylls and carotenoids from marine phytoplankton: a new HPLC method using a reversed phase C-8 column and pyridine-containing mobile phases. Mar Ecol Prog Ser 195:29-45

Zubkov MV, Sleigh MA, Burkill PH, Leakey RJG (2000) Picoplankton community structure on the Atlantic Meridional Transect: a comparison between seasons. Prog Oceanogr 45:369-386

Submitted: July 10, 2009; Accepted: February 24, 2010

Proofs received from author(s): May 3, 2010 